\title{
Mineral Trioxide Aggregate: an overview of composition, properties and clinical applications
}

\author{
Navyasri Kadali1, ${ }^{*}$, Rama Krishna Alla ${ }^{2}$, Vineeth Guduri ${ }^{3}$, Ramaraju AV4, Suresh Sajjan MC \\ Rudraraju Venkateswara Raju ${ }^{5}$ \\ ${ }^{1}$ Lecturer, ${ }^{2}$ Assistant Professor, Department of Dental Materials, Vishnu Dental College, Bhimavaram- \\ 534202, West Godavari, Andhra Pradesh, India. \\ ${ }^{3}$ Reader, 4 Professor, ${ }^{5}$ Lecturer, Department of Prosthodontics and Implantology, Vishnu Dental College, \\ Bhimavaram-534202, West Godavari, Andhra Pradesh, India.
}

\section{N F O R M A T I O N}

\section{Article History}

Received 21st January 2020

Accepted 10th February 2020

Available online

$9^{\text {th }}$ March 2020

\section{K E Y W O R D S}

MTA

$\mathrm{Ca}(\mathrm{OH})_{2}$

Portland cement

Fillapex

\section{A B S T R A C T}

"Mineral trioxide aggregate" is a cementitious material, which is popular by its trade name MTA. MTA is a powder mixture of Portland cement clinker, bismuth oxide, and gypsum. It has gained a lot of importance in dentistry in recent years. This importance is because of its extensive use as apical restorative material as well as a medicament for Apexogenesis and Apexification treatment. As it sets by hydration process, the by products of insoluble calcium silicate hydrate and alkaline calcium hydroxide offer unique stability and potential to enhance hard tissue regeneration. This article reviewed the composition, types, properties of MTA and also its applications in the clinical dentistry.

\section{Introduction}

Mineral Trioxide Aggregate (MTA) was first introduced in the year 1993 by Mohmoud Torabinejad at Loma Linda University in California, USA. MTA has been used on experimental basis by many endodontists for several years. Finally, it was approved for human usage by the U.S. Food and Drug Administration [FDA] in the year 1998[1,2]. MTA appears to be an improvement over other materials for some endodontic procedures that involve root repair and bone healing. This MTA is the only material that supports overgrowth of cementum and formation of bone. MTA has both dentinogenic and osteogenic potential $[3,4]$. Newly developed fast-set MTAs were produced by Pozzolan cement or Zeolite cement. Pozzolan cement is a mineral aggregate with watery calcium silicate hydration. This review aimed to conduct an updated search on the composition, manipulation, types, properties, disadvantages, and clinical applications of MTA. These materials exhibit excellent biocompatibility. MTA provides better protection against microleakage than traditional endodontic repair materials which can be identified using dyes, fluid filtration and bacterial penetration leakage models [4].

Correspondence: *Corresponding author Email Address: navyasri.bandi@vdc.edu.in

How to cite this article: Kadali N, Alla RK, Vineeth G, Ramaraju AV, Suresh Sajjan MC, Raju RV. Mineral Trioxide Aggregate: An overview of composition, properties and clinical applications. Int J Dent Mater 2020;2(1): 11-18. DOI: http://dx.doi.org/10.37983/IJDM.2020.2103 


\section{Composition}

MTA comprises Portland cement (75\%), Bismuth Oxide (20\%), and gypsum (5\%). Portland cement is a mixture of Tricalcium silicate $(\mathrm{CaO})_{3} \mathrm{SiO}_{2}$, Dicalcium silicate $(\mathrm{CaO})_{2} \mathrm{SiO}_{2}$, Tricalcium aluminate $(\mathrm{CaO})_{3} \mathrm{Al}_{2} \mathrm{O}_{3}$, and Tetracalcium aluminoferrite $(\mathrm{CaO})_{4} \mathrm{Al}_{2} \mathrm{O}_{3} \mathrm{Fe}_{2} \mathrm{O}_{3}$. Various commercially available MTA materials are mentioned in table1.

\section{Types of MTA}

MTA is available in two different colours, including white MTA and grey MTA. The colour of the MTA depends on the concentration of $\mathrm{FeO}$ (black), $\mathrm{MgO}$ (white) and $\mathrm{Al}_{2} \mathrm{O}_{3}$. Absence of $\mathrm{FeO}$ in white MTA cause the change in colour from grey to white [6,7]. Compressive strength of Grey MTA is more compared to White MTA. Some MTA formulations contain, for example, MTA Fillapex (Angelus, Londrina, Brazil), resin and these are used as root canal sealing cements. The purpose of the resin addition is to improves or modifies material flow, dentine bonding, and setting time and thereby reducing the micro-leakage. However, it was found that the addition of resin to the MTA materials resulted in the reduction of the desired free $\mathrm{Ca}(\mathrm{OH})_{2}$, which is required for root formation in immatured teeth. NeoMTA (Nusmile, Huston, USA) is a pure MTA that does not contain any resin. It enhances the cost-effectiveness of MTA and mostly used in pulpotomies $[8,9,10]$. The differences between grey and white MTA are described in table 2.

\section{Mechanism of action}

The powder of MTA consisting of inorganic particles is mixed with water; the hydration reaction starts, which is exothermic. It is a dissolution-precipitation process. As the inorganic particles dissolve in water, the nucleation growth process of calcium silicate hydrate and the precipitation of calcium hydroxide helps the hydration rate of MTA. This hydrated cement creates a calcium silicate hydrate based colloidal gel that solidifies to form an impermeable barrier with high alkalinity. As the calcium precipitate forms, the ratio of calcium silicate decreases. According to Koh et al., MTA increase the production of interleukins IL- $1 \alpha$, IL-1 $\beta$, IL-6, IL-8. These interleukins IL- $1 \alpha$, IL- $1 \beta$ activate osteoclasts, thereby results in bone matrix production. IL- 6 and IL8 induce bone resorption and promote the development of new blood vessels. Hence, MTA is having regeneration potential of periodontal ligament and bone $[11,12]$.

\section{Manipulation}

The powder is mixed with sterile water in a ratio of 3:1 (powder to liquid) to prepare MTA [13]. A metal or plastic spatula can be used for mixing on a glass slab or paper pad to form a paste of putty-like consistency. Initial mixing of the material yields a colloidal gel that finally hardens to form a solid structure $[13,14]$. Moisture from the surrounding tissues or wet cotton pellet supports the setting reaction. A paper point, plugger, ultrasonic condensation, or carriers with distinctive designs and messing guns can be used to deliver the MTA mix to the desired location [15]. It was found that

\section{Table 1. Various commercially available MTA products}

\begin{tabular}{ll}
\multicolumn{1}{c}{ Products } & \multicolumn{1}{c}{ Manufacturer } \\
\hline ProRoot MTA & Dentsply Tulsa Dental, Jhonson city, USA \\
WhitePro Root MTA & Dentsply Tulsa Dental, Jhonson city, USA \\
MTA-Angelus(grey) & Angelus, Londrina, Brazil \\
MTA-White & Angelus, Londrina, Brazil \\
EndoCem MTA & Maruchi, Wonju, Korea \\
Endoseal & Maruchi, Wonju, Korea \\
Retro MTA & BioMTA, Korea \\
MTA Fillapex & Angelus, Londrina, Brazil \\
\hline
\end{tabular}


using either doxycycline or chlorhexidine (CHX) instead of distilled water, did not affect on MTA's sealing ability $[13,14]$.

\section{Properties}

\subsection{Physical properties}

These materials provide adequate working time (approximately 5 minutes), whereas the setting time is very long, which ranges from 3 to 4 hours. Therefore, $\mathrm{CaCl}_{2}, \mathrm{Ca}\left(\mathrm{HCO}_{2}\right)_{2}$, and $\mathrm{Na}_{2} \mathrm{HPO}_{4}$ are used as accelerators, which can significantly decrease the setting time of MTA. However, they lower the compressive strength significantly $[18,19]$. On the other hand, using $2 \%$ lidocaine anaesthetic solution and saline lengthen the setting time without affecting the compressive strength. The mixing time of MTA is very crucial. The recommended mixing time is less than 4 minutes. Also, it is preferred to use the mix immediately after mixing to prevent the dehydration and drying into a sandy mixture [20].

\subsection{Compressive strength}

The compressive strength of MTA is around $40 \mathrm{MPa}$ at 24hours, and it was reported as 67.3 MPa after 21 days. It was also reported in the literature that grey MTA exhibits more compressive strength compared to white MTA [5].

\subsection{Radioopacity}

Torabinejad M (1995) reported that mean radioopacity of MTA is $7.17 \mathrm{~mm}$, which is equivalent to the thickness of Aluminium, and adequate to visualise radiographically [5]. Ding SJ (2008) [21] and Shah PMN (1996) [22] found that MTA has comparable radiodensity as Zinc Oxide Eugenol.

\subsection{Solubility}

Increased solubility was observed when MTA is mixed with more water. Buding (2008) found releasing of $\mathrm{Ca}$ $(\mathrm{OH}) 2$ when set MTA is exposed to water. The release of $\mathrm{Ca}(\mathrm{OH}) 2$ is responsible for cementogenesis-inducing property [23].

\section{Table 2. Differences between grey MTA and white MTA}

\section{Grey MTA}

Contains tetracalcium-aluminoferrite, which is responsible for grey discolouration.so, it is not used with the anterior teeth.

Contains large sized particles.

Longer setting time.

Greater compressive strength.

\section{White MTA}

Ferrous oxide is replaced by magnesium oxide, so causes no tooth discolouration.

Contains smaller particles with narrower size distribution.

Shorter setting time.

Lesser compressive strength.

\section{Table 3. Advantages and disadvantages of MTA $[16,17]$}

\section{Advantages}

Disadvantages

- $\quad$ Treated area needs to be infection free when applying MTA, because an acidic environment will prevent MTA from setting.

- Requires operator expertise.

- Difficult to handle MTA as a pulp capping material due to its granular consistency, low strength and initial looseness.

- Expensive. 


\section{$6.5 \mathrm{pH}$}

MTA has an initial $\mathrm{pH}$ of 10.2 that rises to 12.5 three hours after mixing.

\subsection{Antibacterial and antifungal properties}

Al-Hazaimi et al. (2006) reported the antibacterial activity of MTA against enterococcus faecalis and streptococcus sanguis. However, no significant antimicrobial action was observed against anaerobes [24].

\subsection{Biocompatibility}

Sumer et al. (2006) stated that MTA shows excellent biocompatibility [25]. Arens and Torobinejad (1996) treated apical perforations and osseous repair with MTA. Koh et al. proved that MTA can produce interleukins and hence provides an active substrate for the regeneration of bone cells. Kettering and Torabinejad (1995) compared MTA with Super EBA and IRM and found that MTA is not mutagenic and less cytotoxic [26].

\subsection{Marginal adaptation and sealing ability}

MTA exhibits excellent sealing ability as it expands during the setting reaction. So, it is advised to place a moistened cotton pellet in contact with MTA before placing permanent restoration to achieve better sealing. Valois et al. (2004) found that $4 \mathrm{~mm}$ thickness of MTA is adequate to ensure proper sealing [27].

\subsection{Mineralisation}

Holland et al. (1999) [28] theorized that the tricalcium oxide content of MTA interacts with tissue fluids and form $\mathrm{Ca}(\mathrm{OH})_{2}$, similarly resulting in hard-tissue creation to that of $\mathrm{Ca}(\mathrm{OH})_{2}$. Faraco et al. (2001) [29] concluded that the dentin bridge formed with MTA is relatively faster, with excellent structural integrity than with $\mathrm{Ca}(\mathrm{OH})_{2}$. According to Dominguez et al. (2003) [30] and Tziafas (2002) [31], MTA stimulates reparative dentin formation along with maintaining the integrity of the pulp.

\section{Reaction with other dental materials}

MTA does not react or interfere with restorative materials [32]. Glass ionomer cements or composite resins when placed over MTA as permanent restorative materials do not affect the setting of MTA. Some interactions might occur when MTA is combined with other materials during endodontic treatment, and they are as follows;
- Chlorhexidine (CHX): Might cause difficulties for the correct setting.

- Sodium hypochlorite ( $\mathrm{NaOCl}$ ): might cause shorter setting time.

- Saline ( $\mathrm{NaCl})$ : might cause longer setting time.

- Lignocaine: might cause longer setting time.

Advantages and disadvantages of MTA are described in table 3.

\section{Clinical applications of MTA}

\subsection{Pulp capping}

MTA has been used as a potential medicament for pulp capping with reversible pulpitis as it has excellent tissue compatibility. It is much superior to commonly used calcium hydroxide-based cements on the tissue reaction and amount of dentine bridge formed. No tissue necrosis and inflammation are seen with MTA as it is observed with calcium hydroxide. With MTA, dentin bridge formation after pulp capping was seen at about 1 -week that steadily increase in length and thickness within 3-months of capping. Whereas, pulp capping with calcium hydroxide, the dentin bridge was less consistent and exhibited numerous tunnel defects. Aeinehchi et al. in 2003 reported that the formation of dentin bridge was $0.43 \mathrm{~mm}$ thick in 6-months with MTA, whereas it was only $0.15 \mathrm{~mm}$ thick in 6 months when calcium hydroxide was used [33,34].

\subsection{Non-vital pulpotomy}

MTA was tested and found to be an ideal material with low toxic effects, increased tissue regenerating properties and excellent clinical results. The presence of blood has little impact on the setting when $2 \mathrm{~mm}$ thick layer of MTA was placed over pulp during pulpotomy. Discolouration of teeth was observed in $60 \%$ of the deciduous molars treated with MTA. However, this discoloration of the tooth was not a problem as it would be restored with a stainless ssteel crown [34].

\subsection{Vital pulpotomy (apexogenesis)}

It is defined as amputation of coronal pulp completely without inserting anything into the root canal system. This procedure was done mostly for vital teeth with immature roots. Method for placement of a pulp capping, a pulpotomy is as follows [33,34];

- First, bleeding is controlled with cotton moistened with sodium hypochlorite ( $\mathrm{NaOCl}$ ).

- MTA is placed over the exposed pulp using a large amalgam carrier, and the moist cotton pellet is 
placed over it.

- Then, the material is allowed to set, and the rest of the cavity is filled with a temporary filling material.

- In the next appointment that is after 1 -week, the temporary filling is removed along with the cotton pellet and restored with a permanent restoration.

\subsection{Root-end filling}

Endodontic surgery followed by root-end filling is necessary where routine endodontic treatment is not possible. This procedure involves surgical exposure of the root apex, root resection, and plugging the apical foramen with a suitable material that provides a complete apical seal which is non-toxic, nonresorbable, dimensionally stable and radio-opaque. Numerous materials have been used as root-end filling agents, but they fail to prevent leakage. Amalgam most commonly used proved to be much inferior when tested with MTA. MTA treated teeth show less inflammation, more cementum formation and regeneration of periradicular tissues. The procedure includes the following steps [33,34,35];

- $\quad$ The flap is raised under local anaesthesia, followed by ostectomy, root-end resection and hemorrhage control.

- $\quad$ MTA is placed into the root end cavity with a small carrier and packed into place with a plugger.

- $\quad$ The moist environment can be created by inducing mild bleeding from the adjacent tissues and bringing the blood over MTA as placement of wet cotton is not possible.

- The area should not be rinsed after placement of MTA.

- $\quad$ The flap is then sutured back into place.

\subsection{Apical plug (apexification of immature roots)}

The purpose of apexification is to obtain an apical barrier to prevent the extrusion of the obturating material. When calcium hydroxide is used, it may take about 3 to 54 months for the completion of the procedure, which showed a significant reduction in fracture resistance. This problem is solved with the use of MTA $[34,35,36,37]$. An MTA plug of $4 \mathrm{~mm}$ thickness is adequate to form a barrier that seals the periapical area. Steps involved in apical plug formation are as follows;

- An access opening is done under local anaesthesia, and the root canal is cleaned with intracanal irrigants.
- Calcium hydroxide paste can be placed in the canal to disinfect for about 1 -week. It can be removed by rinsing, and excess moisture is removed from the canal.

- $\quad$ Mixed MTA is placed in the cavity using a large amalgam carrier. The material is pushed towards the apical foramen with a plugger or paper points.

- The apical plug should be at least $4 \mathrm{~mm}$ thick, and this should be checked radiographically. If not placed in adequate thickness, the entire material is rinsed and the procedure repeated.

- A moist cotton pellet is placed in the canal and tooth is restored with a temporary restoration.

- After 3 hours, the remaining canal is obturated with gutta-percha, and a permanent restoration should be placed.

\subsection{Obturation of the canal}

MTA can be used to obturate the root canal of a retained primary tooth where the erupting permanent tooth is absent. This material is not recommended for the obturation of primary teeth that are expected to exfoliate since it is anticipated that MTA will be absorbed slowly, if at all used [33,34].

\subsection{Repair of perforation}

For repairing, the clinicians need a material that should be biocompatible, should withstand moisture without dissolving and should have the excellent sealing ability. MTA can also be used for the treatment of perforation that may be caused by an iatrogenic cause or complication of internal resorption [36,38,39].

\subsection{Repair of fracture}

\subsubsection{Horizontal root fracture}

The success rate of the fracture treatment depends on the location (cervical, middle, apical) where it occurs. The root fracture located in the cervical and middle thirds causes difficulty for dental immobilization, leading to injury or even preventing the consolidation of the fragments. For these cases, it is possible to strengthen the tooth with an intra-canal pin cemented with MTA. The canal is instrumented, and then an apical plug with MTA is performed. A metal pin is selected in order to remain adjusted in the canal that is filled with MTA, and the pin is seated inside. Thus, there is reinforcement for the root, preventing mobility of the coronary segment [40-44]. 


\subsubsection{Vertical root fracture}

To repair the vertical fracture, remove the root canal filling material from the treated roots and bond the pieces internally with composite bonded resin. After raising the flap, groove the entire vertical fracture to the composite with a small bur under constant water spray. Place MTA in the groove, cover it with a resorbable membrane, and suture the soft tissue flap. To improve the prognosis of these cases, the patient should be instructed to follow meticulous oral hygiene and the treated tooth should not be probed for at least 12 weeks [45].

\section{Conclusion}

MTA is one of the most promising material to enter the dominion of endodontics in the last few years. MTA is a unique material with various advantages. It has been used successfully in a variety of clinical applications. However, drawbacks, especially high cost, discolouration, difficulty in handling and long setting time cannot be overlooked. Nowadays, Novel Tri-calcium silicate-based materials overcome MTA'S key applications in which it has been used with the recent introduction of new, improved MTA products. MTA based materials are still most widely used because of their superior characteristics and regeneration capacity.

Conflicts of interest: Authors declared no conflicts of interest.

Financial support: None

\section{References}

1. Lee SJ, Monsef M, Torabinejad M. Sealing ability of a mineral trioxide aggregate for repair of lateral root perforations. J Endod. 1993; 19:541-544.

2. Schmitt D, Lee J, Bogen G. Multifaceted use of ProRoot MTA root canal repair material. Pediatr Dent. 2001; 23: 326-330.

3. Srinivasan V, Waterhouse P, Whitworth J. Mineral trioxide aggregate in paediatric dentistry. Int J Pediatr Dent 2009;19:34-47.

4. Casella G, Ferlito S. The use of mineral trioxide aggregate in endodontics. Minerva Stomatol. 2006; 55: 123-143.

5. Torabinejad M, Hong CU, McDonald F, Ford TR. Physical and chemical properties of a new root -end filling material. J Endod. 1995; 21: 349-353.
6. Parirokh M, Torabinejad M. Mineral trioxide aggregate: a comprehensive literature review-Part I: chemical, physical, and antibacterial properties. J Endod. 2010; 36: 16-27.

7. Kratchman SI. Perforation repair and one-step apexification procedures. Dent Clin North Am. 2004; 48: 291-307.

8. Camilleri J. Staining potential of Neo MTA Plus, MTA Plus, and biodentine used for pulpotomy procedures. J Endod. 2015; 41: 1139-1145.

9. Camilleri J. Hydration characteristics of Biodentine and Theracal used as pulp capping materials. Dent Mater. 2014; 30: 709-715.

10. Khan J, El-Housseiny A, Alamoudi N. Mineral Trioxide Aggregate Use in Pediatric Dentistry: A Literature Review. J Oral Hyg Health. 2016; 4: 209.

11. Camilleri J, Pitt Ford TR. Mineral trioxide aggregate: a review of the constituents and biological properties of the material. Int Endod J. 2006; 39: 747-754.

12. Camilleri J, Montesin FE, Brady K, Sweeney R, Curtis $\mathrm{RV}$, et al. The constitution of mineral trioxide aggregate. Dent Mater. 2005; 21: 297-303.

13. Torabinejad M, Watson TF, Pitt Ford TR. Sealing ability of a mineral trioxide aggregate when used as a root end filling material. J Endod. 1993; 19: 591-595.

14. Macwan C, Deshpande A. Mineral trioxide aggregate (MTA) in dentistry: A review of literature. J Oral Res Rev. 2014; 6: 71-74.

15. Arruda RA, Cunha RS, Miguita KB, Silveira CF, De Martin AS, et al. Sealing ability of mineral trioxide aggregate (MTA) combined with distilled water, chlorhexidine, and doxycycline. J Oral Sci. 2012; 54: 233-239.

16. Srinivasan V, Waterhouse $P$, Whitworth J. Mineral trioxide aggregate in paediatric dentistry. Int J Paediatr Dent. 2009; 19: 34-47.

17. Steinig TH, Regan JD, Gutmann JL. The use and predictable placement of Mineral Trioxide Aggregate in one-visit apexification cases. Aust Endod J. 2003; 29: 34-42.

18. Kogan P, He J, Glickman GN, Watanabe I. The effects of various additives on setting properties of MTA. J Endod. 2006; 32: 569-572.

19. Prasad A, Pushpa S, Arunagiri D, Sawhny A, Misra A, et al. A comparative evaluation of the effect of various additives on selected physical properties of white mineral trioxide aggregate. J Conserv Dent. 2015; 18: 237-241.

20. Sluyk S, Moon P, Hartwell G. Evaluation of setting 
properties and retention characteristics of mineral trioxide aggregate when used as a furcation perforation repair material. J Endod. 1998; 24: 768-771.

21. Ding SJ, Kao CT, Shie MY, Hung C Jr, Huang TH. The physical and cytological properties of white MTA mixed with $\mathrm{Na} 2 \mathrm{HPO} 4$ as an accelerant. J Endod 2008;34:748-51.

22. Shah PM, Chong BS, Sidhu SK, Pitt Ford TR. Radio opacity of potential root end filling materials. Oral Surg Oral Med Oral Pathol Oral Radiol Endod 1996;81:476-9.

23. Budig CG, Eleazer PD. In vitro comparison of the setting of dry ProRoot MTA by moisture absorbed through the root. J Endod 2008;34:712-4.

24. Al-Hezaimi K, Al-Shalan TA, Naghshbandi J, Oglesby $\mathrm{S}$, Simon JH, Rotstein I. Antibacterial effect of two mineral trioxide aggregate (MTA) preparations against Enterococcus faecalis and Streptococcus sanguis in vitro. J Endod 2006;32:1053-6.

25. Sumer M, Muglali M, Bodrumlu E, Guvenic T. Reactions of connective tissue to amalgam, intermediate restorative material, mineral trioxide aggregate mixed with chlorhexidine. J Endod 2006;32:1094-6.

26. Kettering JD, Torabinejad M. Investigation of mutagenicity of mineral trioxide aggregate and other commonly used root-end filling materials. J Endod 1995;21:537-42.

27. Valois CR, Costa ED Jr. Influence of the thickness of mineral trioxide aggregate on sealing ability of root-end filling in vitro. Oral Surg Oral Med Oral Pathol Oral Radiol Endo 2004;97:108-11.

28. Holland R, de Souza V, Nery MJ, Otoboni Filho JA, Bernabé PF, Dezan Júnior E. Reaction of dogs' teeth to root canal filling with mineral trioxide aggregate or a glass ionomer sealer. J Endod 1999;25:728-30.

29. Faraco IM Jr, Holland R. Response of the pulp of dogs to capping with mineral trioxide aggregate or a calcium hydroxide cement. Dent Traumatol 2001;17:163-6.

30. Dominguez MS, Witherspoon DE, Gutmann JL, Opperman LA. Histological and scanning electron microscopy assessment of various vital pulptherapy materials. J Endod 2003;29:324-33.

31. Tziafas D, Pantelidou O, Alvanou A, Belibasakis G, Papadimitriou $S$. The dentinogenic effect of mineral trioxide aggregate (MTA) in short term capping experiments. Int Endod J 2002;35:245 54.
32. Nandini S, Ballal S, Kandaswamy D. Influence of glass Ionomer cement on the interface and setting reaction of mineral trioxide aggregate when used as a furcal repair material using laser Raman spectroscopic analysis. J Endod 2007;33:167-72.

33. Torabinejad M, Chivian N. Clinical applications of mineral trioxide aggregate. J Endod. 1999;25 (3):197-205.

34. Hedge R, Battepati. Clinical applications of MTA: report of four cases. Int J Clin Pediat Dent. 2010; 3 (1):43-50.

35. Torabinejad M, Pitt Ford TR, McKendry DJ, Abedi HR, Miller DA, Kariyawasam SP. Histologic assessment of mineral trioxide aggregate as a root-end filling in monkeys. J Endod. 1997;23(4):225-228.

36. Simon S, Rilliard F, Berdal A, Machtou P, Simon S, Rilliard F, Berdal A, Machtou P. The use of mineral trioxide aggregate in one-visit apexification treatment: a prospective study. Int Endodont J. 2007;40:186-197.

37. El-Meligy OA, Avery DR. Comparison of apexification with mineral trioxide aggregate and calcium hydroxide. Pediatr Dent. 2006; 28: 248-53.

38. Pitt Ford TR, Torabinejad M, Hong CU, Kariyawasam SP. Use of mineral trioxide aggregate for repair of furcal perforations. Oral Surg 1995;79;756-63.

39. Sarris S, Tahmassebi JF, Duggal MS, Cross IA. A clinical evaluation of mineral trioxide aggregate for root-end closure of non-vital immature permanent incisors in children-a pilot study. Dent Traumatol. 2008; 24: 79-85.

40. Bramante CM, Menezes R, Moraes IG, Bernardinelli N, Garcia RB, et al. Use of MTA and intracanal post reinforcement in a horizontally fractured tooth: a case report. Dent Traumatol. 2006; 22: 275-278.

41. Erdem AP, Ozdas DO, Dincol E, Sepet E, Aren G. Case series: Root healing with MTA after horizontal fracture. EurArch Paediatr Dent. 2009; 10:110-113.

42. Yildirim T, Gencoglu N. Use of mineral trioxide aggregate in the treatment of horizontal root fractures with a 5-year follow-up: report of a case. J Endod. 2009; 35: 292-295.

43. Sheikh-Nezami M, Mokhber N, Shamsian K, Saket S. Management of a mid-root and complicated crown fracture: A case report. Oral Surg Oral Med Oral Pathol Oral Radiol Endod. 2009; 107: e65-67.

44. Roig M, Espona J, Mercade M, Duran-Sindreu F. Horizontal root fracture treated with MTA, a case report with a 10-year follow-up. Dent Traumatol. 2011; 27: 460-463. 
properties and retention characteristics of mineral trioxide aggregate when used as a furcation perforation repairmaterial. J Endod. 1998; 24: 768-771.

21. Ding SJ, Kao CT, Shie MY, Hung C Jr, Huang TH. The physical and cytological properties of white MTA mixed with Na2HPO4 as an accelerant. J Endod 2008;34:748-51.

22. Shah PM, Chong BS, Sidhu SK, Pitt Ford TR. Radio opacity of potential root end filling materials. Oral Surg Oral Med Oral Pathol Oral Radiol Endod 1996;81:476-9.

23. Budig CG, Eleazer PD. In vitro comparison of the setting of dry ProRoot MTA by moisture absorbed through the root. J Endod 2008;34:712-4.

24. Al-Hezaimi K, Al-Shalan TA, Naghshbandi J, Oglesby $\mathrm{S}$, Simon JH, Rotstein I. Antibacterial effect of two mineral trioxide aggregate (MTA) preparations against Enterococcus faecalis and Streptococcus sanguis in vitro. J Endod 2006;32:1053-6.

25. Sumer M, Muglali M, Bodrumlu E, Guvenic T. Reactions of connective tissue to amalgam, intermediate restorative material, mineral trioxide aggregate mixed with chlorhexidine. J Endod 2006; 32:1094-6.

26. Kettering JD, Torabinejad M. Investigation of mutagenicity of mineral trioxide aggregate and other commonly used root-end filling materials. J Endod 1995;21:537-42.

27. Valois CR, Costa ED Jr. Influence of the thickness of mineral trioxide aggregate on sealing ability of root-end filling in vitro. Oral Surg Oral Med Oral Pathol Oral Radiol Endo 2004;97:108-11.

28. Holland R, de Souza V, Nery MJ, Otoboni Filho JA, Bernabé PF, Dezan Júnior E. Reaction of dogs' teeth to root canal filling with mineral trioxide aggregate or a glass ionomer sealer. J Endod 1999;25:728-30.

29. Faraco IM Jr, Holland R. Response of the pulp of dogs to capping with mineral trioxide aggregate or a calcium hydroxide cement. Dent Traumatol 2001;17:163-6.

30. Dominguez MS, Witherspoon DE, Gutmann JL, Opperman LA. Histological and scanning electron microscopy assessment of various vital pulptherapy materials. J Endod 2003;29:324-33.

31. Tziafas D, Pantelidou O, Alvanou A, Belibasakis G, Papadimitriou $S$. The dentinogenic effect of mineral trioxide aggregate (MTA) in short term capping experiments. Int Endod J 2002;35:245 54.

32. Nandini S, Ballal S, Kandaswamy D. Influence of glass ionomer cement on the interface and setting reaction of mineral trioxide aggregate when used as a furcal repair material using laser Raman spectroscopic analysis. J Endod 2007;33:167-72.

33. Torabinejad M, Chivian N. Clinical applications of mineral trioxide aggregate. J Endod. 1999;25 (3):197-205.

34. Hedge R, Battepati. Clinical applications of MTA: report of four cases. Int J Clin Pediat Dent. 2010; 3 (1):43-50.

35. Torabinejad M, Pitt Ford TR, McKendry DJ, Abedi HR, Miller DA, Kariyawasam SP. Histologic assessment of mineral trioxide aggregate as a root-end filling in monkeys. J Endod. 1997;23(4):225-228.

36. Simon S, Rilliard F, Berdal A, Machtou P, Simon S, Rilliard F , Berdal A, Machtou P. The use of mineral trioxide aggregate in one-visit apexification treatment: a prospective study. Int Endodont J. 2007;40:186-197.

37. El-Meligy OA, Avery DR. Comparison of apexification with mineral trioxide aggregate and calcium hydroxide. Pediatr Dent. 2006; 28: 248-53.

38. Pitt Ford TR, Torabinejad M, Hong CU, Kariyawasam SP. Use of mineral trioxide aggregate for repair of furcal perforations. Oral Surg 1995;79;756-63.

39. Sarris S, Tahmassebi JF, Duggal MS, Cross IA. A clinical evaluation of mineral trioxide aggregate for root-end closure of non-vital immature permanent incisors in children-a pilot study. Dent Traumatol. 2008; 24: 79-85.

40. Bramante CM, Menezes R, Moraes IG, Bernardinelli $\mathrm{N}$, Garcia RB, et al. Use of MTA and intracanal post reinforcement in a horizontally fractured tooth: a case report. Dent Traumatol. 2006; 22: 275-278.

41. Erdem AP, Ozdas DO, Dincol E, Sepet E, Aren G. Case series: Root healing with MTA after horizontal fracture. EurArch Paediatr Dent. 2009; 10:110-113.

42. Yildirim T, Gencoglu N. Use of mineral trioxide aggregate in the treatment of horizontal root fractures with a 5-year follow-up: report of a case. J Endod. 2009; 35: 292-295.

43. Sheikh-Nezami M, Mokhber N, Shamsian K, Saket S. Management of a mid-root and complicated crown fracture: A case report. Oral Surg Oral Med Oral Pathol Oral Radiol Endod. 2009; 107: e65-67.

44. Roig M, Espona J, Mercade M, Duran-Sindreu F. Horizontal root fracture treated with MTA, a case report with a 10-year follow-up. Dent Traumatol. 2011; 27: 460-463.

45. Kim S, Kratchman S. Modern endodontic surgery concepts and practice: A review. J Endod. 2006; 32: 601-623. 